\title{
Effect of transplanting times on pollen and spikelet sterility, growth and yield of aman rice
}

\author{
MA Jalil, IJ Shelley, MHR Pramanik*, MA Karim \\ Department of Crop Botany, Bangladesh Agricultural University, Mymensingh 2202, Bangladesh
}

\begin{abstract}
A field experiment was conducted to study the effect of planting dates on pollen/spikelet sterility, grain development and yield of hybrid rice in T. Aman season. The two varieties: Heera-4 (hybrid) and BINAdhan-7 (inbred) were transplanted on five consecutive dates at fifteen days interval viz. 15 July, 30 July, 15 August, 30 August and 15 September of 2011. The effect of variety and transplanting date showed significant variation in pollen sterility, grain growth \& development, panicle length, filled grains panicle ${ }^{-1}$, spikelet sterility and grain yield. Pollen sterility was the highest in Heera-4 (>80\%) consequently spikelet sterility for transplanting on 15 July while transplanting on 30 July low pollen sterility consequently spikelet sterility. Both early or late transplanting affected grain growth and development, enhanced pollen sterility as well as spikelet sterility and reduced grain yield. Late transplanting (30 August and 15 September) significantly reduced panicle length and filled grains panicle ${ }^{-1}$. Transplanting on 30 July gave low pollen sterility as well as spikelet sterility, high panicle length and high filled grains panicle ${ }^{-1}$ consequently greater grain yield in the varieties.
\end{abstract}

Key words: Rice, temperature, pollen sterility, spikelet sterility, grain growth

Progressive Agriculturists. All rights reserve

*Corresponding Author: habiburp@yahoo.com

\section{Introduction}

Rice is grown in Bangladesh round the year and the varieties grown in different seasons (Aus, Aman \& Boro) possess some specific characteristics for adaptation in each season (Singh and Singh, 2000). Rice yield of both local and HYVs differs among the seasons having maximum in Boro season and minimum in Aus season. This high yield in Boro season is commensurate with sufficient light intensity, less cloudy, low humidity and significant differences in day and night temperatures. Optimum temperature for tiller production in rice is $25-31{ }^{\circ} \mathrm{C}$, for anthesis is 30 $33^{\circ} \mathrm{C}$ and for ripening is $20-29^{\circ} \mathrm{C}$ and the temperature less than $15^{\circ} \mathrm{C}$ at panicle initiation stage causes spikelet sterility (Yoshida, 1981). Spikelet sterility occurred due to both low and high temperatures prevailing from panicle initiation to flowering stages of rice (Zhong et al., 1991; Nahar et al., 2009; Shelley et al., 2016). The temperature below $18^{\circ} \mathrm{C}$ at flowering stage promoted the spikelet sterility in hybrid e.g. Sonarbangla 1 and BRRIdhan-29. The hybrid, Sonarbangla 1 was moderately resistant to spikelet sterility while BRRIdhan-29 was much vulnerable to spikelet sterility under different planting dates (Amin et al., 2004). Temperature prevailing below $18^{\circ} \mathrm{C}$ for two or more days during panicle initiation and booting stage leads to spikelet sterility while temperature at $35^{\circ} \mathrm{C}$ or above (Matsui et al., 1997) during flowering stage also enhances spikelet sterility resulting significant yield 
loss in rice (Muniruzzaman, 2009). In greenhouse experiments with both indica and japonica genotypes less than $1 \mathrm{~h}$ of exposure to temperature above $33 \cdot 7^{\circ} \mathrm{C}$ was sufficient to induce sterility (Jagadish, 2007).

Temperature, day length, solar radiation, precipitation, relative humidity, etc vary with the seasons and planting times of crops, and those variations have significant effect on growth and yield of rice. The time of planting, which is related to light, temperature and moisture content in soil, is the most important factor influencing the growth and yield of crops. It is possible to increase the grain yield of hybrid rice by planting at early or optimum time (Pan et al., 1998 and Om et al., 1993) but late planting reduces the yield of rice due to shortening of vegetative period. Determination of optimum time of planting is more important in case of hybrid rice because of its relatively high degree of thermo-sensitivity during the flowering and grainfilling stages compared to conventional inbred high yielding varieties (Nayak et al., 2003). In Bangladesh, hybrid rice has already gained positive experience in Boro season but its production in T. Aman season is scanty even at research level. The present experiment was undertaken to observe the performances of hybrid rice (Heera-4) along with inbred rice (BINAdhan-7) under different dates of transplanting in $\mathrm{T}$. Aman season. Therefore, the objectives of the study were to study the effects of different transplanting dates on the pollen as well as spikelet sterility, grain growth and yield of hybrid and inbred rice in T. Aman season as well as to find out their optimum date of transplanting.

\section{Materials and Methods}

The experiment was conducted at the Field Laboratory of the Department of Crop Botany, Bangladesh Agricultural University, Mymensingh during the Aman season from June to December 2011. A hybrid rice variety, Heera-4 and BINAdhan-7 (inbred check) were used as test crop in the experiment. Sprouted seeds were successively sown in seedbeds at 15 days interval so that the seedlings at 25-day old could be transplanted in main field at 15 July, 30 July, 15 August, 30 August and 15 September to create natural variation of temperature and photoperiod. Standard cultivation procedures were followed for all the transplanting dates. Fertilizers viz. nitrogen, phosphorus, potassium, sulphur and zinc were uniformly applied corresponding to the rate of 75-20-40-10-2 $\mathrm{kg} \mathrm{ha}^{-1}$ in the form of urea, triple super phosphate, muriate of potash, gypsum and zinc sulphate, respectively as per BARC fertilizer recommendation guide (BARC, 2005). The urea was top dressed in two installments as per the recommendation guide.

Pollen sterility measurement: Pollen sterility test was furnished through microscopic observation (Khatun and Flowers, 1995). Florets having anthers just after anthesis were brought to the laboratory for immediate microscopic observations. One drop of the potassium iodide $(\mathrm{KI})$ solution was taken in a slide and then the anthers were ruptured by mild tapping within the KI drop. The pollen cells with cytoplasm took stain and became red while those devoid of cytoplasm did not take any stain. The slides prepared with KI and pollen grains were placed under the objective of microscope to count sterile (non-stained) and nonsterile pollens (stained). At the time of anthesis ten representative spikelets from ten different plants were collected from each cultivar from each replication for the different transplanting dates. Pollen grains were collected from the representative spikelets of the second or third branch from top on the primary rachis. The spikelets were xed in 50\% ethanol soon after collection and stained with $1 \%$ potassium iodide (KI) solution for sterility measurement. Pollen sterility was estimated as the ratio of number of stained pollens to the total number of pollens within the focus area of the microscope and expressed as percentage.

Grain development: From each plot immediately after anthesis randomly five panicles were harvested and then taken to the laboratory. The panicles were dried in 
oven at $80^{\circ} \mathrm{C}$ for 24 hours and 100 spikelets from the five panicles were randomly separated and their gross weight was recorded in an electronic balance. The same procedure was followed for both the variety for each of the five transplanting dates at five days interval after anthesis to maturity. Data obtained were analyzed and plotted in graphical forms for final presentation.

Before final harvesting at maturity ten hills were randomly selected in each unit plot and those were harvested separately to record the panicle length, filled grains panicle ${ }^{-1}$, spikelet sterility, grain \& straw yield and harvest index. Maximum and minimum air temperature during the experimental period were collected from the weather yard station of Bangladesh Agricultural University, Bangladesh and presented in graphical form in the text of the article.

Harvest index (HI) is the ratio of economic yield to biological yield (Gardner et al., 1985). It was calculated by using the following formula

Harvest index $(\%)=\frac{\text { Economic yield }}{\text { Biological yield }} \times 100$

The data collected on different parameters under the experiments were statistically analyzed to obtain the level of significance using the computer MSTAT package program developed by Russel (1986). The differences between pairs of means were compared by Duncan's multiple range test (DMRT) as stated by Gomez and Gomez (1984).

\section{Results and Discussion}

Pollen sterility: A hybrid rice (Heera-4) along with a modern cultivar BINAdhan-7 was transplanted on different dates to evaluate their growth performance in T. Aman season. Pollen sterility percentage was estimated with $1 \%$ Potassium Iodide (KI) solution at anthesis through microscopic observation (Plates $1 \&$ 2; Figure 1). Transplanting dates had significant effect on pollen sterility of the rice varieties. Seedlings transplanted on 15 July produced the highest pollen
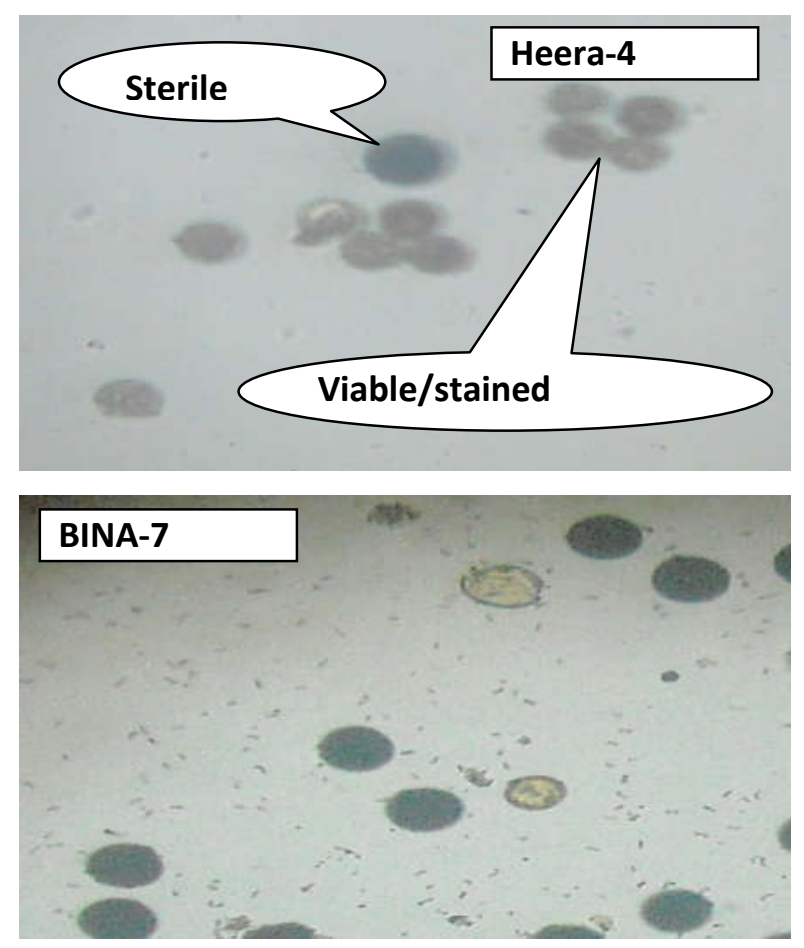

Plate 1. Rice pollen grains for transplanting on 15 July
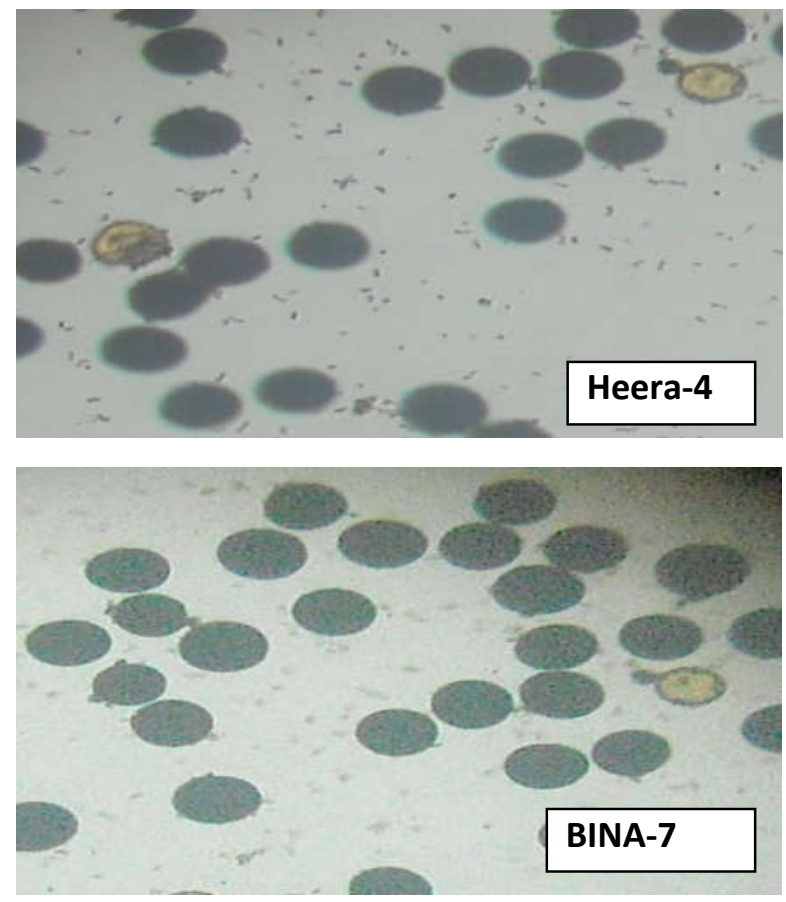

Plate 2. Rice pollen grains at anthesis for transplanting on 30 July 
sterility $(>80 \%)$ in Heera-4 while those transplanted on 15 August for both the varieties produced lowest sterility $(<25 \%)$. Temperature is one of the important factors affecting pollen as well as spikelet sterility in rice. Pollen grains easily get desiccated by high temperature $\left(37^{\circ} \mathrm{C}\right.$ or above) and the high temperature on anthesis induced sterility. Optimum temperature for rice anthesis is $30-33^{\circ} \mathrm{C}$ and for ripening is $20-29^{\circ} \mathrm{C}$ (Yoshida, 1981).

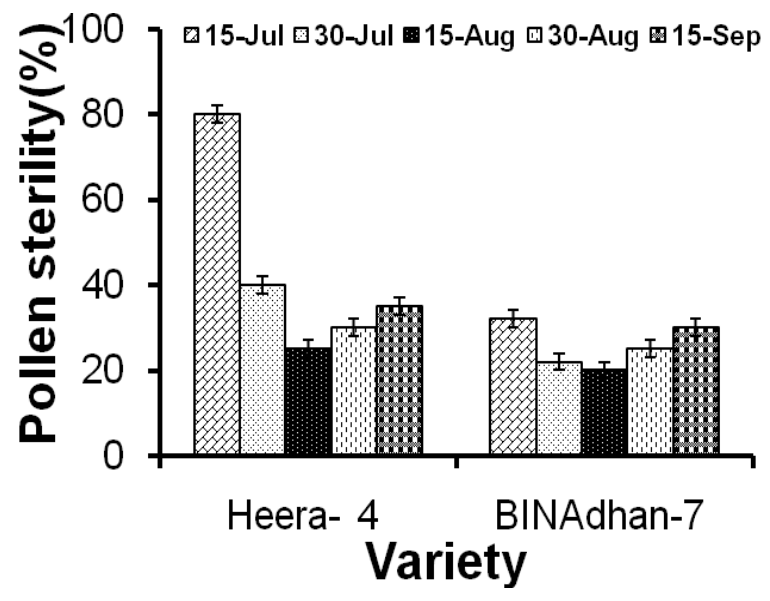

Figure 1. Variation in pollen sterility percentage of the rice varieties (Heera-4 and BINAdhan-7) over the reproductive phase transplanted at different times

Thus, the maximum air temperature $\left(>34^{\circ} \mathrm{C}\right)$ during study period till 7 October (Figure 3) was higher than the optimum one which might enhance the pollen as well as spikelet sterility in the rice varieties. Similar findings were reported by (Nakagawa et al., 2003; Matsui et al., 1997). They reported that temperature higher than the optimum temperature induced pollen/ oret sterility.

Grain growth and development: Grain growth in rice is a sequential phenomenon and it starts immediately after anthesis or fertilization. Grain growth and development was measured by the 100-grain weight recorded at five days interval till maturity. 100-grain weight after anthesis is one of the most important yield contributing characters in cereals. Figure 2 represents the grain development in Heera-4 and BINAdhan-7. Initial slow grain development till five days after anthesis followed a rapid and sigmoid growth pattern in both the varieties. Physiological maturity i.e. no increment of dry matter was observed between 30 to 35 days after anthesis in both the varieties. However, changes in transplanting dates induced significant variation on grain filling. At physiological maturity maximum 100-grain weight (2.6 g) was recorded in Heera-4 transplanted on 30 July followed by BINAdhan-7 (2.4 g) (Figure 2).
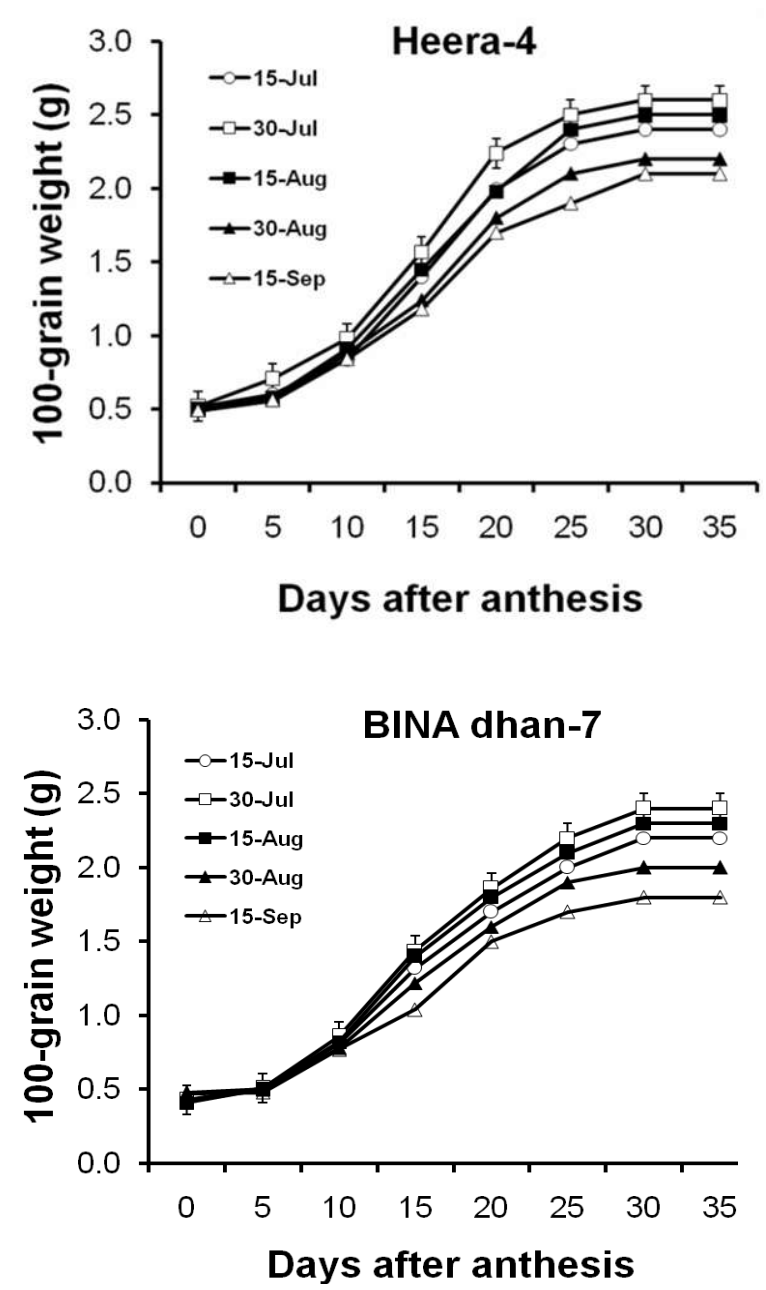

Figure 2. Variation of 100-grain weight after anthesis of the rice varieties over the reproductive phase transplanted at different times 
Early or late transplanting of the varieties was not favorable for healthy grain development. Being the varieties are day neutral, early transplanting (15 July) resulted early anthesis which commensurate with the prevailing high temperature (Figure 3) resulting in decline of 100-grain weight (Figure 2) possibly for enhanced respiration at the high temperature. On the other hand the late transplanting of rice seedlings (30 Aug or $15 \mathrm{Sep}$ ) had late anthesis leading to late grain formation when low temperature prevails $\left(<20^{\circ} \mathrm{C}\right)$ (Figure 3). Cardinal air temperature for rice ranged from $15^{\circ} \mathrm{C}$ to $33^{\circ} \mathrm{C}$ although sometimes winter temperature goes below $7^{\circ} \mathrm{C}$ in Bangladesh (Haque et al., 2004). Optimum temperature for rice anthesis was $30-33^{\circ} \mathrm{C}$ and for ripening was $20-29^{\circ} \mathrm{C}$ (Yoshida, 1981) or $21-22^{\circ} \mathrm{C}$ (Amin, 2004). Temperature regulated respiration and translocation, and at temperature below $21^{\circ} \mathrm{C}$, translocation usually decelerated, while at temperature above $22^{\circ} \mathrm{C}$ the respiration rate was accelerated and the grain-filling period shortened (Amin, 2004). This leads to the conclusion that transplanting of Aman rice, on 30 July or around it appeared to be the optimum time for favourable growth and development of rice grains.

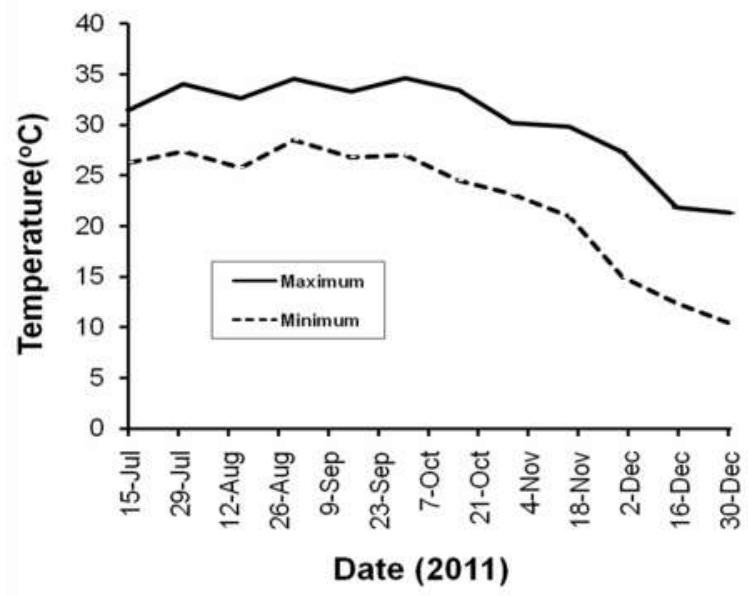

Figure 3. Maximum and minimum air temperature during the experimental period

Panicle length: Panicle length, counted from basal node of the rachis to the apex of the panicle, varied significantly with transplanting dates. The average panicle length was the longest $(28.3 \mathrm{~cm})$ in hybrid compared to inbred BINAdhan-7 $(20.3 \mathrm{~cm})$ (Figure 4). The seedlings transplanted on 30 July produced longest panicle length $(27.75 \mathrm{~cm})$ and those transplanted on 15 September produced the shortest $(20.75 \mathrm{~cm})$. The interaction effect of variety and planting date had exhibited significant variation on panicle length too (Figure 4).

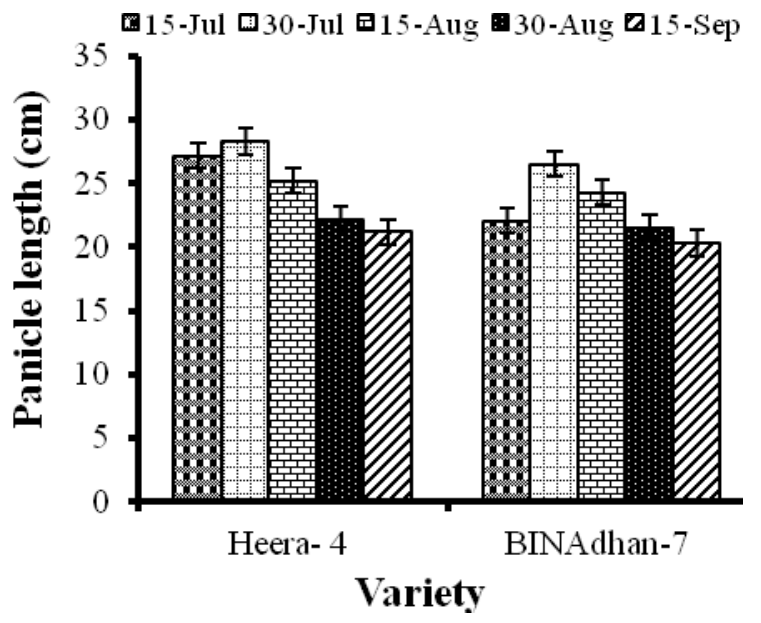

Figure 4. Variation in panicle length $(\mathrm{cm})$ of the rice varieties over the reproductive phase transplanted at different times

Panicle length of a rice plant is dependent on variety, management practices, drought, fertilizers, soil fertility, etc. The panicle length of the genotype CR 874-59 was observed to be highest $(28.8 \mathrm{~cm})$ followed by $\mathrm{CR}$ 2008-129 (26.9 cm) (Patnaik and Mohanty, 2006). Whereas, BINAdhan-5 produced the longest panicle $(22.86 \mathrm{~cm})$ followed by BRRI dhan-29 $(22.7 \mathrm{~cm})$ and BINAdhan-6 (22.28 cm) (Chakma, 2006). Hybrids, in general, produced longer panicle length compared to HYV cultivars (Ghosh, 2001). Thus, the variation in panicle length between the hybrid and inbred (BINAdhan-7) could be attributed to their genotypic variation along with natural environmental variation created by different transplanting dates. 
Filled grains panicle ${ }^{-1}$ : The results show that variety had significant effect on filled grains panicle ${ }^{-1}$. The highest filled grains panicle ${ }^{-1}$ was observed inbred rice BINAdhan-7 (136) and the lowest in Heera-4 (78). Planting time had significant effect on filled grains panicle $^{-1}$. It was observed that the seedlings transplanted on 30 July produced maximum filled grains panicle ${ }^{-1}$ in BINAdhan-7 (Figure 5). Unlike pollen sterility, early or late transplanting of Aman rice had significant effect on filled grains panicle ${ }^{-1}$ and the seedlings transplanted on 15 July produced lowest filled grains panicle ${ }^{-1}$ (23) (Figure 6). The result correlates with the findings of pollen sterility (Figure 1). The interaction effect of variety and planting date had exhibited significant variation of filled grains panicle $^{-1}$. The highest filled grains panicle ${ }^{-1}$ was reported in BINAdhan-7 (135) when it was transplanted on 30 July.

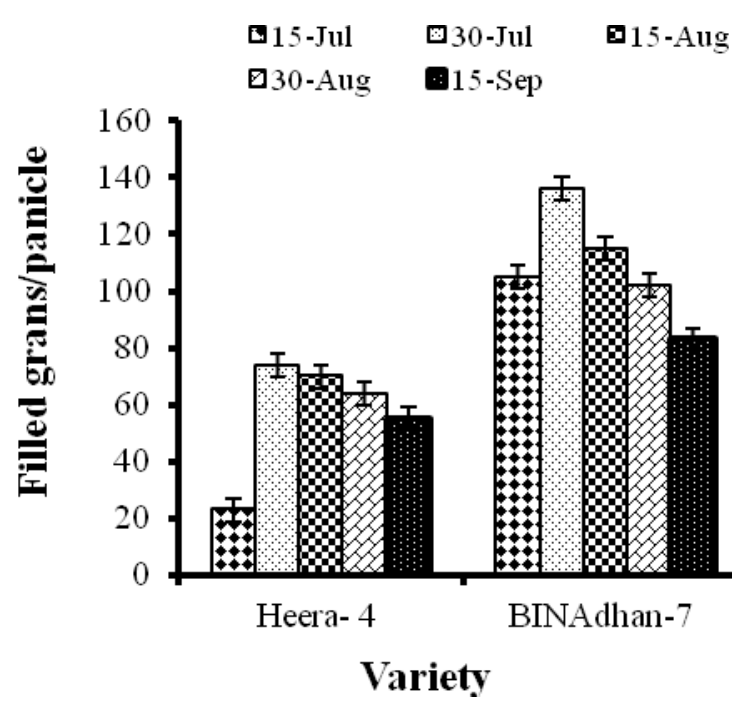

Figure 5. Variation in filled grains/panicle of the rice varieties over the ripening phase transplanted at different times

Spikelet sterility percent: The spikelets are main yield attribute of a cereal and its filling or unfilling dependent on many factors such as genotypes, environmental factors, management practices, etc. Pollen sterility also led to spikelets sterility as the sterile pollens cannot fertilize eggs. Figure 1 reveals that the early or late transplanting of T. Aman rice corresponded to the anthesis period at high or low temperature (Figure 3) due to natural variation created by different transplanting dates. Thus, early transplanting led to anthesis at high temperature resulting high spikelet sterility $(>80 \%)$ in hybrid rice Heera-4 compared to BINAdhan-7 (Fig.6 and Plates 1 \&2). This indicates that Heera-4 is more thermosensitive than BINA-7. Figure 6 reveals that the seedlings transplanted on 15 July produced maximum spikelet sterility and those transplanted on 30 August produced lowest spikelet sterility (Plates $1 \& 2$ ).

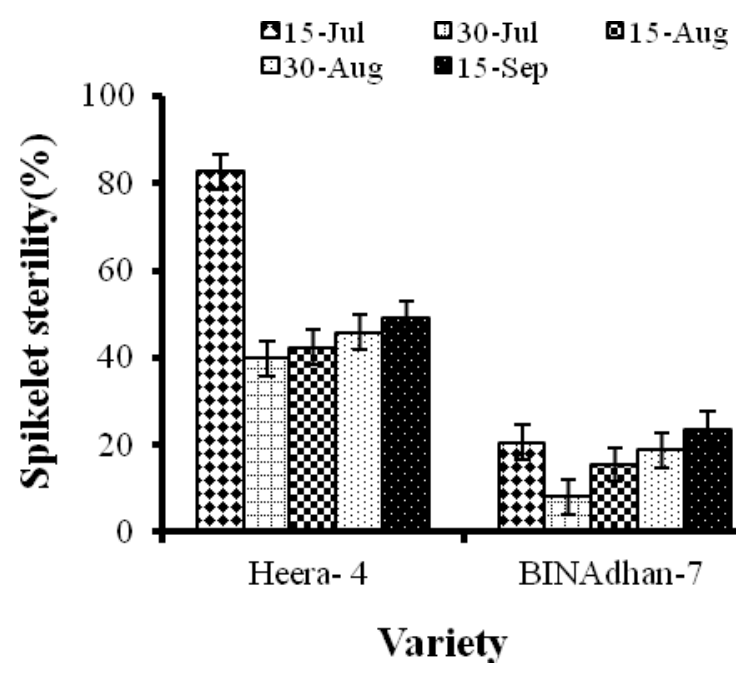

Figure 6. Variation in spikelet sterility (\%) of the rice varieties over the ripening phase transplanted at different times

The hybrid rice has mainly been originated through genetic manipulation in China possessing a temperate climate with low temperature which is different from the climate of Bangladesh. Because of temperate origin, the hybrid rice adapted well in the temperature range $20-25^{\circ} \mathrm{C}$ (Hari et al., 1997). So, high temperature stress or low temperature chilling injury might enhance the pollen fertility as well as spikelet sterility in the rice varieties (Figure $1 \& 6$ ). 
Grain and straw yield: Harvesting high grain yield is the ultimate objective of crop growth and thus, grain is the primary target for crop cultivation. Both the hybrid and inbred varieties exhibited significantly varied grain yield for different transplanting dates (Table 1). Average grain and straw yield were $2.3 \& 2.7 \mathrm{t} \mathrm{ha}^{-1}$ in BINAdhan-7 and 1.8 and $3.1 \mathrm{t} \mathrm{ha}^{-1}$ Heera-4, respectively.

Table 1. Effect of variety and times of transplanting on the yield and yield contributing characters of hybrid and inbred rice grown in T. Aman season

\begin{tabular}{|c|c|c|c|}
\hline Treatments & $\begin{array}{l}\text { Grain } \\
\text { yield } \\
\text { (tha) }\end{array}$ & $\begin{array}{l}\text { Straw } \\
\text { yield } \\
\text { (tha) }\end{array}$ & $\begin{array}{l}\mathrm{HI} \\
(\%)\end{array}$ \\
\hline \multicolumn{4}{|l|}{ Variety } \\
\hline Heera-4 (V1) & $1.8^{\mathrm{b}}$ & $3.1^{\mathrm{a}}$ & $35.7^{\mathrm{b}}$ \\
\hline $\begin{array}{l}\text { BINA dhan-7 } \\
\text { (V2) }\end{array}$ & $2.3^{\mathrm{a}}$ & $2.7^{\mathrm{b}}$ & $46.8^{\mathrm{a}}$ \\
\hline \multicolumn{4}{|l|}{$\begin{array}{l}\text { Transplanting } \\
\text { time }\end{array}$} \\
\hline 15 July $\left(\mathrm{D}_{1}\right)$ & $1.8^{\mathrm{c}}$ & $2.7^{\mathrm{b}}$ & $39.5^{\mathrm{b}}$ \\
\hline 30 July $\left(\mathrm{D}_{2}\right)$ & $3.4^{\mathrm{a}}$ & $4.4^{\mathrm{a}}$ & $43.1^{\mathrm{a}}$ \\
\hline 15 Aug $\left(D_{3}\right)$ & $2.2^{\mathrm{b}}$ & $2.9^{\mathrm{b}}$ & $43.1^{\mathrm{a}}$ \\
\hline $30 \operatorname{Aug}\left(\mathrm{D}_{4}\right)$ & $1.7^{\mathrm{c}}$ & $2.5^{\mathrm{bc}}$ & $39.9^{\mathrm{b}}$ \\
\hline $15 \operatorname{Sept}\left(D_{5}\right)$ & $1.4^{\mathrm{d}}$ & $2.0^{\mathrm{c}}$ & $40.9^{\mathrm{b}}$ \\
\hline \multicolumn{4}{|l|}{$\begin{array}{l}\text { Interaction } \\
(\mathbf{V} \times \mathbf{D})\end{array}$} \\
\hline $\mathrm{V}_{1} \mathrm{D}_{1}$ & $1.4^{\mathrm{f}}$ & $2.8^{\mathrm{c}}$ & $33.5^{\mathrm{c}}$ \\
\hline $\mathrm{V}_{1} \mathrm{D}_{2}$ & $2.9^{\mathrm{b}}$ & $4.6^{\mathrm{a}}$ & $38.7^{\mathrm{b}}$ \\
\hline $\mathrm{V}_{1} \mathrm{D}_{3}$ & $2.0^{\mathrm{de}}$ & $3.0^{\mathrm{c}}$ & $40.0^{\mathrm{b}}$ \\
\hline $\mathrm{V}_{1} \mathrm{D}_{4}$ & $1.4^{\mathrm{f}}$ & $2.8^{\mathrm{c}}$ & $33.4^{\mathrm{c}}$ \\
\hline $\mathrm{V}_{1} \mathrm{D}_{5}$ & $1.2^{\mathrm{g}}$ & $2.4^{\mathrm{de}}$ & $33.3^{\mathrm{c}}$ \\
\hline $\mathrm{V}_{2} \mathrm{D}_{1}$ & $2.1^{\mathrm{d}}$ & $2.5^{\mathrm{d}}$ & $45.7^{\mathrm{a}}$ \\
\hline $\mathrm{V}_{2} \mathrm{D}_{2}$ & $3.8^{\mathrm{a}}$ & $4.2^{\mathrm{b}}$ & $47.5^{\mathrm{a}}$ \\
\hline $\mathrm{V}_{2} \mathrm{D}_{3}$ & $2.4^{\mathrm{c}}$ & $2.8^{\mathrm{c}}$ & $46.2^{\mathrm{a}}$ \\
\hline $\mathrm{V}_{2} \mathrm{D}_{4}$ & $1.9^{\mathrm{e}}$ & $2.2^{\mathrm{e}}$ & $46.4^{\mathrm{a}}$ \\
\hline $\mathrm{V}_{2} \mathrm{D}_{5}$ & $1.5^{\mathrm{f}}$ & $1.6^{\mathrm{f}}$ & $48.4^{\mathrm{a}}$ \\
\hline
\end{tabular}

In a column means having similar letter(s) do not differ significantly as per DMRT at 5\% level
The maximum grain yield in BINAdhan-7 could be associated with the lowest sterility percentage while the low grain yield in Heera-4 could be attributed to the high pollen/spikelets sterility percentage (Figure 1 \& 6). Transplanting dates induced significant grain and straw yield variation in the varieties. The results reveal that grain and straw yield was maximum on 30 July transplantation in both the varieties and thereafter grain and straw yield gradually declined with subsequent delay in planting till last transplantation on 15 September (Table 1). Reduced grain and straw yield in late transplanting in Aman wsa reported by many researchers (Anita and Dasgupta, 1998; Krishnan and Nayak et al., 1997; Rao et al., 1996; Ali et al., 1995; Om et al., 1993). The interaction of transplanting dates and variety had significant effect on grain yield. The maximum grain yield $\left(3.8 \mathrm{t} \mathrm{ha}^{-1}\right)$ was harvested from 30 July transplantation for inbred BINAdhan-7 and the minimum grain yield $\left(1.2 \mathrm{t} \mathrm{ha}^{-1}\right)$ was from 15 September transplantation for hybrid rice Heera-4 (Table 1). The results led to the conclusion that too early (15 July) or late (15 August or onwards) transplantation in Aman season of both the varieties, hybrid Hera-4 and inbred BINAdhan-7, gave poor grain/ straw yield and their transplantation on 30 July appears to be suitable for cultivation (Table 1). And high straw yield in the hybrid variety compared to the inbred could be attributed to its long lasting (till maturity) greenness in leaves which might favor high accumulation of dry matter through photosynthesis till harvesting.

Harvest index (HI): Harvest index is the ratio of economic yield to biological yield. In general, grain is the economic yield in case of cereals while grain and straw yield together considered as biological yield. Varieties exerted a significant effect on harvest index. BINAdhan-7 had the maximum harvest index (48.4\%) and the minimum straw yield $(1.6 \mathrm{t} / \mathrm{ha})$ (Table 1). Harvest index has been reported to decrease with the increase in plant 
height (IRRI, 1988). As the hybrid rice Heera-4 was taller than BINA dhan-7 (data not shown) they produced lower HI. HI was significantly influenced by the dates of transplanting that means variation in temperature. The high HI was recorded from the transplanting on July 30 and the lowest from September 15. This might correspond to high grain yield from former planting and low grain yield from latter planting (Table1). Results presented in Table 1 indicated that the highest harvest index (48.4\%) was recorded in BINAdhan-7 on September 15 transplanting and the lowest (33.3\%) in hybrid rice Heera- 4 at the same transplanting date. The results suggested that 30 July transplantation appeared to be optimum for harvesting high yield in Aman season and hybrid rice (Heera-4) may not be profitable for cultivation in Aman season.

\section{References}

Ali MY, Rahman MM, Haq MR (1995). Effect of time of transplanting and age of seedling on the performance of late planted aman rice. Bangladesh J. Sci. Ind. Res., 30: 45-53.

Amin AKMR (2004). Effect of cold temperature and agronomic management on the spikelet sterility and yield of Boro rice. Ph. D. thesis, Dept. Agron., BAU, Mymensingh, Bangladesh.

Amin MGM, Ali MH, Islam AKMR (2004). AgroClimate analysis for planning in Bangladesh. $J$. Agri. Engg., 15: 31-40.

Anita S, Dasgupta DK (1998). Effect of delayed transplanting on yield and yield attributes of rice cv. Sabita and Utkalprave. Environ. Ecol., 16: 471-473.

BARC (2005). Fertilizer Recommendation Guide. 2005. Bangladesh Agricultural Research Council, Farmgate, Dhaka-121, pp. 25-28.

Chakma S (2006). Influence of Spacing on the Growth and Yield Attributes of Modern Boro Rice Varieties. M.S. Thesis, Dept. Crop Bot., Bangladesh Agric. Univ., Mymensingh
Gardner F,P Pearce RB, Mistecell RI (1985). Physiology of Crop Plants. Iowa Univ. State Press., Iowa, P.66.

Ghosh M (2001). Performance of hybrid and highyielding rice varieties in Teraj region of West Bengal. J. Int. Academicians, 5: 578-581.

Gomez KA, Gomez AA (1984). Statistical procedures for agricultural research. 2nd edn. John Wiley and Sons, New York, p.680.

Hari OM, Katyal SK, Dhimn SD (1997). Effect of time of transplanting and rice hybrids on growth and yield. Indian J. Agron., 42: 261-264.

Haque MA, Khaliq QA, Karim A, Ahmed J, Rahman MH (2004). Nitrogen fertilizer effect on dry matter production and grain growth of aromatic rice. J. Subtrop. Agric. Res. Dev., 2: 15-19.

IRRI (1988). Annual Report for 1976. International Rice Research Institute, Los Banos, Philippines. p. 218.

Jagadish SVK, Craufurd PQ, Wheeler TR (2007). High temperature stress and spikelet fertility in rice (Oryza sativa L.). J Exp. Bot., 58: 1627-1635.

Khatun S, Flowers TJ (1995). The estimation of pollen viability in rice. J. Exp. Bot., 46: 151154.

Krishnan P, Nayak SK (1997). Effect of seedling age and planting time on growth and yield of photosensitive rice (Oryza sativa) varieties. Indian J. Agril. Sci., 67: 77-78.

Matsui T, Namuco OS, Ziska LH, Horie T (1997). Effects of high temperature and $\mathrm{CO} 2$ concen tration on spikelet sterility in indica rice. Field Crop Res., 51: 213-219.

Moniruzzaman MM (2009). Increase or decrease of rice yield as affected by weather, cultivation and management practices. In: "The Guardian". pp. 36-37.

Nahar K, Hasanuzzaman M, Majumder RR (2009). Effect of low temperature stress in transplanted aman rice varieties mediated by different transplanting dates. Academic J Plant Sci., 2: 132-138. 
Nakagawa H, Horie T, Matsui T (2003). Effects of climate change on rice production and adaptive technologies. In Rice Science: Innovations and Impact for Livelihood. Proceedings of the International Rice Research Conference, Beijing, China, 16-19 September 2002 (Eds T.W. Mew, D. S. Brar, S. Peng, D. Dawe \& B. Hardy), pp. 635-658.

Nayak BC, Dalei BB, Choudhury BK (2003). Response of hybrid rice (Oryza sativa) to date of planting, spacing and seedling rate during wet season. Indian J. Agron., 48: 172-174.

Om H, Singh OP, Joon RK (1993). Effect of time of transplanting and spacing on Basmati rice. Haryana J. Agron., 9: 87.

Pan X, Qu W, Pan XB (1998). Analysis on the main agronomic characters and discussion of high yield breeding of early indica Hybrid rice. Indian $J$. Agron., 43: 68-70.

Rao KS, Moorthy BTS, Dash AB, Lodh SB (1996). Effect of time of transplanting on grain yield and quality traits of Bamotitype scented rice varieties in coastal Orissa. Indian J. Agril. Sci., 66: 333-337.

Shelley IJ, Takahashi-Nosaka M, Kano-Nakata, M Haque MS, Inukai Y (2016). Rice cultivation in Bangladesh: present scenario, problems and prospects. J. Intl. Agric. Dev., 14: 20-29.

Singh S, Singh TH (2000). Response of maize crop to early and late summer sowing conditions. Indian J. Plant Physiol., 5: 307-313.

Yoshida S (1981). Fundamentals of Rice Crop Science. Intl. Rice Res. Inst., Los Banos, Leguna, Philippines, pp 48 -269.

Zhong GR (1991). Advance in research on cold tolerance in rice. Jiangshu J. Agril. Sci., 7: 52-56. 